\title{
BIM AIDED INFORMATION AND VISUALIZATION REPOSITORY FOR MANAGING CONSTRUCTION DELAY CLAIMS
}

SUBMITTED: November 2020

REVISED: June 2021

PUBLISHED: December 2021

EDITOR: Žiga Turk

DOI: $10.36680 /$ j.itcon.2021.054

Babar Ali, PhD Student,

Faculty of Architecture, Building and Planning, Melbourne School of Design, The University of Melbourne;

Email: babar.ali@student.unimelb.edu.au

Hafiz Zahoor, Assistant Professor,

Department of Construction Engineering and Management, NUST College of Civil Engineering,

National University of Sciences and Technology, Risalpur Campus, 24080, Pakistan;

Email: hafiz.zahoor@mce.nust.edu.pk (Corresponding author)

Ajibade Aibinu, Associate Professor,

Faculty of Architecture, Building and Planning, Melbourne School of Design, The University of Melbourne;

Email:aaibinu@unimelb.edu.au

Abdur Rehman Nasir, Assistant Professor,

Department of Construction Engineering and Management, SCEE,

National University of Sciences and Technology, Islamabad, 44000, Pakistan;

Email:abdur.nasir@nit.nust.edu.pk

Ali Tariq, Lecturer,

Faculty of Civil Engineering, Abasyn University, Islamabad Campus, 45710, Pakistan;

Email: ali.tariq94@gmail.com

Umair Imran, Graduate Student,

Department of Construction Engineering and Management, NUST College of Civil Engineering,

National University of Sciences and Technology, Risalpur Campus, 24080, Pakistan;

Email: umairimran302@gmail.com

Rashid Mehmood Khan, Graduate Student,

Department of Management Sciences, National University of Modern Languages, Islamabad, 44000, Pakistan;

Email: rashidmehmoodkhan@gmail.com

SUMMARY: Delays in construction result in a multitude of negative effects on project performance, and severe dismays among participating parties. This study aims to digitize the traditional process of recording and managing the construction delays using Building Information Modeling (BIM). Extensive literature review followed by semistructure interviews of 21 industry experts were carried out to identify the issues faced by construction stakeholders in managing construction delays. To resolve these issues, a plugin named BIM-based Construction Delays Recorder (BIM-CDR) is developed using Application Programming Interface (API) of the most commonly used BIM software i.e. Autodesk Revit. BIM-CDR provides a centralized repository, encompassing detailed information related to delays, which can be retrieved and visualized to analyze their impact on delay claims. To assess the effectiveness of BIM-CDR, a feasibility study is conducted with the experts' review panel. The results revealed that BIM-CDR can record wide-ranging information related to all the significant issues causing delays on construction sites, and can help in effectively managing their corresponding claims. The advantages of the developed prototype include visualization of delays' location, facilitation of delay analysis and effective delays management. Moreover, it also promotes transparency and speedy settlement of delay related claims without any unwanted disputes.

KEYWORDS: Construction delays, Building Information Modeling, Application Programming Interface, Plugin, Delay analysis, Claims

REFERENCE: Babar Ali, Hafiz Zahoor, Ajibade Aibinu, Abdur Rehman Nasir, Ali Tariq, Umair Imran, Rashid Mehmood Khan (2021). BIM aided information and visualization repository for managing construction delay claims. Journal of Information Technology in Construction (ITcon), Vol. 26, pg. 1023-1040, DOI: 10.36680/j.itcon.2021.054

COPYRIGHT: () 2021 The author(s). This is an open access article distributed under the terms of the Creative Commons Attribution 4.0 International (https://creativecommons.org/licenses/by/4.0/), which permits unrestricted use, distribution, and reproduction in any medium, provided the original work is properly cited. 


\section{INTRODUCTION}

Delays are recognized as the fact of life for construction projects (Braimah, 2013). They are inevitable (Arif and Morad, 2013), and are considered as one of the most recurring problems in the construction industry (Mahamid $e t$ al., 2011). Various factors leading to delays in construction projects include, but not limited to, unrealistic contract time, improper resource planning, unforeseen conditions, delay in issuance of drawings, errors in documentations, rework and improper risk distribution (Hanna et al., 2017; Larsen et al., 2015). Besides, delays can be attributed to lack of management skills and poor coordination among key stakeholders (Farrow, 2007). These delays result in multitude of negative effects on project performance, including additional time and cost to complete the project. To compensate these losses, an extension of time (EOT) and/or additional cost are claimed by the contractor, for the reasons which are not contractor's responsibility (Kumaraswamy, 1997). Similarly, an employer can impose liquidated damages (LDs) in the form of monetary compensation, for the delays caused by the contractor (Hanna et al., 2017; Scott, 1997). The determination of one of these measures depends upon the responsibility of delays, which can be constituted after proper analysis and investigation (Muhamad et al., 2016). Yet, there are certain existing challenges that hinder the accurate and efficient analysis of construction delays, which are discussed in the ensuing sub-section.

\subsection{Issues in construction delays management}

The analysis of construction delays starts with the identification of causes and responsibilities of delays, followed by understanding its impact on project and contracting parties. Owing to the fact that construction projects have become more complicated in recent years. with the involvement of multiple stakeholders, each with their own set of performance requirements (Akintoye and Skitmore, 1991; Pickavance, 2010), the process of managing the delays of a project by isolating its actual causes and deciding about the right amount of responsibilities and impacts, has become very challenging (Schumacher, 1995).

One of the common difficulties in managing the delays of construction projects is the lack of an effective system for record keeping of the information related to delays (Enshassi et al., 2009; Scott et al., 2004). Mostly, delays related information resides in the head of key project staff (Tan and Anumba, 2010), and the departure of such staff, compounded by inefficient document management system, results in the loss of vital information required for delay analysis (Palaneeswaran and Kumaraswamy, 2008). In addition, information retrieval and visualization are two other major issues highlighted by Burr and Pickavance (2010) in identifying delays' responsibilities and their impacts. Retrieving correct delay related information is a serious concern if not organized (Palaneeswaran and Kumaraswamy, 2008). One of the most problematic issues faced by the participating parties during delay analysis is overdue in retrieving the delays related information (Enshassi et al., 2009; Vidogah and Ndekugri, 1997). Similarly, lack of platform for visualization of delays also plays a key role in complicating the process of understanding and analysing the impacts of these delays (Gibbs et al., 2014). Apart from these, certain unattended issues also need to be explored, as they are mainly responsible for non-satisfactory and poor delay analysis. A nonsatisfactory delay analysis leads to dispute between contracting parties (Kumaraswamy, 1997), which are damaging the contractor as well as employer in terms of cost and time spending (Marzouk et al., 2008). According to Arcadis (2020), the cost involved in global construction disputes in year 2020 was $\$ 30.7$ million which lasted for 15 months. These disputes rottenly result in bad blood between the contracting parties (Shabbar et al., 2017).

In order to resolve the issues to manage construction delays, an efficient platform is required. The past studies have recommended to develop a centralized digital hub that can provide the most updated and readily accessible delay information to all parties involved in the project (Gibbs et al., 2014). Similarly, visualization of such information is also recommended in anticipating the impacts of delays and minimizing the difficulties in analysis of construction delays (Marzouk et al., 2018). Building Information Modeling (BIM), a modern Information and Communication Technology (ICT) platform, can help by providing instant, digital and visualized information for construction delays (Gibbs et al., 2014). This research, therefore, exploits BIM to resolve the current issues in managing construction delays and provides a centralized database for recording and visualizing the construction delays. The objectives of this research are set as:

- To identify the problematic issues in the management of construction delays.

- To equip the construction stakeholders with a modern digital platform which can help in resolving the issues identified in the management of construction delays. 


\subsection{A review of construction delays management with BIM}

BIM is a shared digital representation easing the process of design, construction and operation (Azhar et al., 2009). It acts as an engineering database that allows data accumulation for effective information management (Lee et al., 2018). According to NBS (2017), "BIM can embrace the contract documents, specifications, properties, personnel, programming, quantities, cost of each item, spaces and geometry". The key features of BIM are the ability to demonstrate $3 \mathrm{D}$ presentations, to retain the significant information in a digital format to facilitate the update, and to transfer the information in a shared environment (Ho et al., 2013). Being an information management resource, BIM can act as an effective platform for managing the delays related information.

The construction industry can use BIM platform to provide electronic, visual and demonstrative evidence of delays (Gibbs et al., 2014). With implementation of BIM in start of a project, adequate project information can be kept in a centralized database connected to a 3D model, provided all recommendations for record keeping are followed. This database can assist to identify, quantify and visualize the delays and their impact occurring on projects (Gibbs et al., 2014). Though, visualization function of BIM is primarily used to communicate design, however, its advantages can be realized for a variety of purposes in the project lifecycle (Bouchlaghem et al., 2005). One such benefit is to visualize delays in projects to understand its impact. BIM can also minimize the potential conflicts and disputes arising from delays and their corresponding claims (Gibbs et al., 2014; Shahhosseini and Hajarolasvadi, 2018). However, BIM has yet not been efficiently utilized for dealing with delays in construction projects (Gibbs et al., 2014; Marzouk et al., 2018). This can be attributed to the fact that BIM's platforms and tools do not have any in-built functionality to deal with construction delays.

Providentially, Application Programming Interface (API) is a feature of BIM platforms and tools, which provides aid to develop add-ins or plugins utilising the existing capabilities of BIM platforms and tools, thus enabling it to accomplish the specialized tasks (Akinade et al., 2016). For instance, Shen and Marks (2015) have developed a near-miss database plugin for construction safety in one of the BIM software (Shen and Marks, 2015). Other such plugins already developed in BIM environment, include: recording of construction quality defects information (Ying-Mei, 2017); development of a hybrid solution for real-time environmental monitoring and notification system for buildings, using BIM and Wireless Sensors Network (Arslan et al., 2014); estimating variations in project completion period due to the time ripple effect (Moayeri et al., 2017); integration of BIM with wireless sensors to monitor construction workers safety in confined spaces (Riaz et al., 2014); and development of claim management system for EOT claims in BIM (Ali et al., 2020).

The aforesaid studies and inventions present an argument for combining API's strengths with BIM to create a digital system that acts as a visual repository for resolving difficulties that lead to the poor management of construction delays. Consequently, a prototype, named BIM-based Construction Delays Recorder (BIM-CDR), is developed in this study, for efficient management of the delays in construction projects.

\section{RESEARCH METHODOLOGY}

To achieve the objectives, this research adopts and modifies the framework proposed by Azhar et al. (2009) for conducting research in construction engineering and management, as shown in Fig. 1. The study's methodology comprises of following three phases, which are explicated in succeeding sub-sections.

1. In the first phase, literature review and semi-structured interviews with 19 industry experts were conducted to identify the problems in the management of construction delays.

2. Next, a cross functional framework in BIM environment is developed to propose a digitized system for resolution of the identified issues. Using the proposed framework, a real time plugin (i.e. BIM-CDR) is developed in Autodesk Revit for managing construction delays.

3. Lastly, the proposed system is tested/evaluated for its efficacy using reviews / feedback of industry experts. 


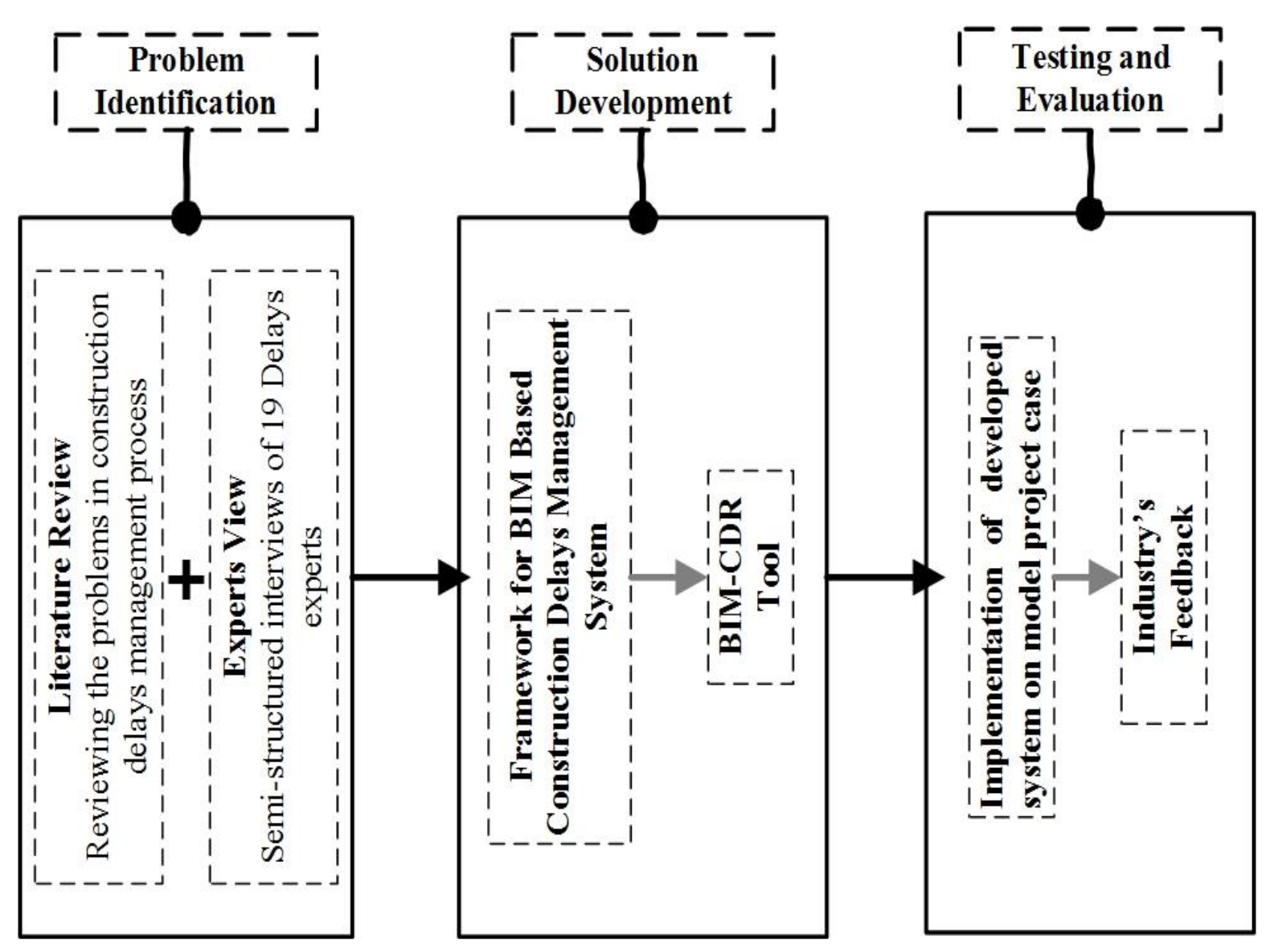

FIG.1: Research methodology

\subsection{Problem identification}

In the first phase, problematic issues encountered during the management of construction delays were identified through substantial literature review. It was observed that vast literature is available on the factors causing delays in construction projects. However, limited research had been conducted to identify the issues leading to poor management of these delays, which consequently hinder the project performance. After carefully exhausting the literature focusing on the issues associated with the management of delays in construction projects, eighteen papers were shortlisted to acquire the issues hindering the effective management of construction delays. Owing to overlapping problems with different names and same meanings, content analysis was performed to screen out less significant problems (Hsieh and Shannon, 2005). This resulted in shortlisting of twenty-eight problematic issues in management of delays.

Next, 21 contract experts were interviewed in semi-structured interviews to analyze the shortlisted issues and propose additional significant issues. Being a phenomenological nature of the study, involving subject experts to explore the problems they face practically, it met the sample size requirements for qualitative research methods, which are typically between 5 to 25 for phenomenological qualitative interviews. (Creswell, 1998). The process of interviewing the experts was stopped on reaching the saturation, once the additional interviews could not produce new information or data (Guest et al., 2006). A varied sample of experts was purposefully selected from contracting and engineering profile, enriched with the experience of dealing with construction delays on local as well as international projects. The profile of interviewees is shown in Table 1. The interviews' format was semistructured, which allows asking set questions and probing when needed (Abd El-Razek et al., 2008). The experts were asked to comment on the delay related issues which they experienced while dealing with construction projects and were requested to highlight if an important issue is missing. 
Table 1: Profile of experts

\begin{tabular}{lcccc}
\hline Company type & Role & $\begin{array}{c}\text { No of } \\
\text { participants }\end{array}$ & $\begin{array}{c}\text { Construction experience } \\
\text { in years }\end{array}$ & $\begin{array}{c}\text { International projects } \\
\text { experience in years }\end{array}$ \\
\hline Contractor & Contract manager & 7 & $16-40$ & $14-35$ \\
& Planning manager & 6 & $17-28$ & $12-20$ \\
\multirow{2}{*}{ Engineer } & Contract manager & 4 & $13-26$ & $10-17$ \\
& Planning manager & 4 & $13-21$ & $10-15$ \\
\hline
\end{tabular}

To gain a broader understanding of the root causes of issues, interviewees were also requested to choose a suitable group from a list of group names for each issue that has been selected. The outcomes of this segment are presented in result section of this paper.

\subsection{Solution development}

In the second phase, the prototype i.e. BIM-CDR was developed for managing the construction delays using BIM. Autodesk Revit Architecture 2017 (BIM platform), Structured Query Language (SQL) Server (Database Management System), and Visual Studio.Net were used to construct the prototype (Software Development Environment). The reason for using Autodesk Revit Architecture as BIM platform was its good visual presentation and ease of connectivity with external database (Riaz et al., 2014). Moreover, Autodesk Revit's API provides a fully customizable.NET Program Development Toolkit for user interface and software logic development (Akinade, 2017). The prototype was created with Microsoft Visual Studio and the widely used multi-paradigm programming language C\#. The API of Autodesk Revit software was also used to create a data link between Autodesk Revit Architecture software and SQL Server.

\subsection{Evaluation}

According to Paek (2001), any developed system can be assessed by determining how well it meets the requirements for which it was created, as well as the areas that could be improved. In this research, the developed prototype is evaluated through experts' review, as done by Ali et al. (2020) for their research related to development of a plugin for EOT claims in construction industry. Fifteen industry experts were selected to be part of experts' review panel. They were all well knowledgeable on the subject matter. Nine of these professionals (including five contractors and four engineers) were approached for identification of the problems faced during delays' management. Three of these experts had a minimum of 8-year experience of working in the contracts department of employer. While, last three experts had worked as BIM coordinator and engineer. Despite the limited sample size, the study covered the entire range of people involved in construction contracts.

These experts were asked to state their thoughts on the new system's effectiveness. One-on-one assessment sessions were conducted with the experts. They were given information about the study's context, BIM platform, as well as, summary and demonstration of the tool that has been built. Instructions, animations, and demonstrations of all BIM-CDR functionalities were included in the demonstration.

For evaluation of the developed prototype, a public-sector medical complex was chosen as a model project. Using BIM-CDR, different types of delays that could occur during the construction of model project were recorded and visualized for the experts. After the demonstration, experts were asked to fill up the questionnaire, followed by recording their views through semi-structured interviews. The questionnaire was designed according to the evaluation criteria of ICT related systems i.e. inquiring about the developed tool need, effectiveness, benefits and usability. Ali et al. (2020), and Riaz et al. (2014) also used similar criteria to evaluate their developed systems for construction claims and workers safety. A five-point Likert scale (with 1 representing 'strongly disagree' to 5 representing 'strongly agree') was adopted to record the experts' opinion (Zahoor et al., 2017). All experts were presented with a finalized list of problematic issues in the construction delays management process to evaluate the effectiveness of the designed system against the identified problems in construction delays management. Relative important index (RII) technique was adopted using Eq. (1) to prioritize the "issues resolution capability" of the developed digital system (Ali et al., 2020).

$$
\mathrm{RII}=\frac{\sum \mathrm{W}}{\mathrm{AxN}} \quad(0 \leq \mathrm{RII} \leq 1)
$$


Where, $\mathrm{W}$ depicts the respondents' weighting of each factor; A depicts the highest weight, i.e. 5, and $\mathrm{N}$ constitutes the total number of respondents. Later, during semi-structured interviews, experts' perspectives were recorded by creating debate about the effectiveness of BIM-CDR.

\section{RESULTS}

\subsection{Problematic issues in the management of construction delays}

The twenty-eight issues identified through literature review were eventually reduced to twenty-five, after analyzing the results of semi-structured interviews. These shortlisted issues were clustered in 7 groups, as summarized in Table 2 .

Table 2: Shortlisting the issues confronted in the management of construction delays

\begin{tabular}{|c|c|c|c|}
\hline No & Issues in delays management & Group & Reference \\
\hline 1 & $\begin{array}{l}\text { Inaccessibility of supporting documents needed } \\
\text { for notice }\end{array}$ & Documentation & Enshassi et al. (2009), and Bakhary et al. (2015) \\
\hline 2 & Unavailability of records for analysis & Documentation & Enshassi et al. (2009) \\
\hline 3 & Ineffective record keeping system & Documentation & Yoke-Lian et al. (2012), and Bakhary et al. (2015) \\
\hline 4 & Overdue in retrieving the needed information & Time & Enshassi et al. (2009) \\
\hline 5 & $\begin{array}{l}\text { Lack of timely decision by the Engineer regarding } \\
\text { delays }\end{array}$ & Time & $\begin{array}{l}\text { Maduranga et al. (2017), Yates and Epstein (2006), and } \\
\text { Alnaas et al. (2014) }\end{array}$ \\
\hline 6 & Lack of timely notifications by contractors & Time & Braimah (2013), and Maduranga et al. (2017) \\
\hline 7 & Engineer requests for excessive details & Time & Yoke-Lian et al. (2012) \\
\hline 8 & $\begin{array}{l}\text { Difficulty in categorization of different types of } \\
\text { delays }\end{array}$ & Contractual & $\begin{array}{l}\text { Scott et al. (2004), Alkass et al.(1995), and Palaneeswaran } \\
\text { and Kumaraswamy (2008) }\end{array}$ \\
\hline 9 & Lack of details submitted with notice & Contractual & Yoke-Lian et al. (2012) \\
\hline 10 & Poor paperwork by the contractor & Contractual & Yoke-Lian et al. (2012), and Braimah (2013) \\
\hline 11 & Concurrent delays & Contractual & $\begin{array}{l}\text { Yates and Epstein (2006), Scott et al. (2004), Alkass et al. } \\
\text { (1995), and Palaneeswaran and Kumaraswamy (2008) }\end{array}$ \\
\hline 12 & Identification of responsibility of delay & Contractual & $\begin{array}{l}\text { Enshassi et al. (2009), Braimah (2013), and Scott et al. } \\
(2004)\end{array}$ \\
\hline 13 & Noncompliance with contract requirements & Contractual & $\begin{array}{l}\text { Hassanein and El Nemr (2008), Yusuwan and Adnan (2013), } \\
\text { and Enshassi et al. (2009) }\end{array}$ \\
\hline 14 & Departure of related personnel from project & Resource & Palaneeswaran and Kumaraswamy (2008) \\
\hline 15 & Poor workmanship & Resource & Yates and Epstein (2006) \\
\hline 16 & Lack of manpower and resources & Resource & Alnaas et al. (2014) \\
\hline 17 & No computerized documentation system & Resource & $\begin{array}{l}\text { Enshassi et al. (2009), Carmichael and Murray (2006), and } \\
\text { Alkass et al. (1995) }\end{array}$ \\
\hline 18 & Lack of communication & Procedure & Bakhary et al. (2015) \\
\hline 19 & Complexity in determining cause and effect & Procedure & $\begin{array}{l}\text { Vidogah and Ndekugri (1997), Carmichael and Murray } \\
(2006) \text {, and Palaneeswaran and Kumaraswamy (2008) }\end{array}$ \\
\hline 20 & Lack of updated program & Procedure & $\begin{array}{l}\text { Braimah (2013), Maduranga et al. (2017), and Vidogah and } \\
\text { Ndekugri (1997) }\end{array}$ \\
\hline 21 & Verbal Instructions & Procedure & Enshassi et al. (2009) \\
\hline 22 & Misleading information & Procedure & Yates and Epstein (2006) \\
\hline 23 & Difficulty in visualization of delays impact & Presentation & Burr and Pickavance (2010), and Gibbs et al. (2014) \\
\hline 24 & Presentation of delays & Presentation & Braimah (2013) \\
\hline 25 & Exaggeration of delays impact by contractor & Cost & $\begin{array}{l}\text { Palaneeswaran and Kumaraswamy (2008), and Bakhary et } \\
\text { al. (2017) }\end{array}$ \\
\hline
\end{tabular}




\subsection{BIM-CDR framework}

The framework for BIM-CDR tool is shown in Fig. 2. The BIM-CDR application is connected to a database (SQL server) and interacts with the BIM platform for inputs. It has the provision of recording either the contractor's delay or Engineer/Employer's delay. Accordingly, delaying element is selected to record the delay event and related information (contractor's delay or Engineer/Employer's delay), which is stored in the database. The recorded delay events are then displayed in BIM-CDR Delay Register. All the recorded delay elements can be recognized in 3D in Autodesk Revit model, and the information related to delay event can be viewed and updated at any stage.

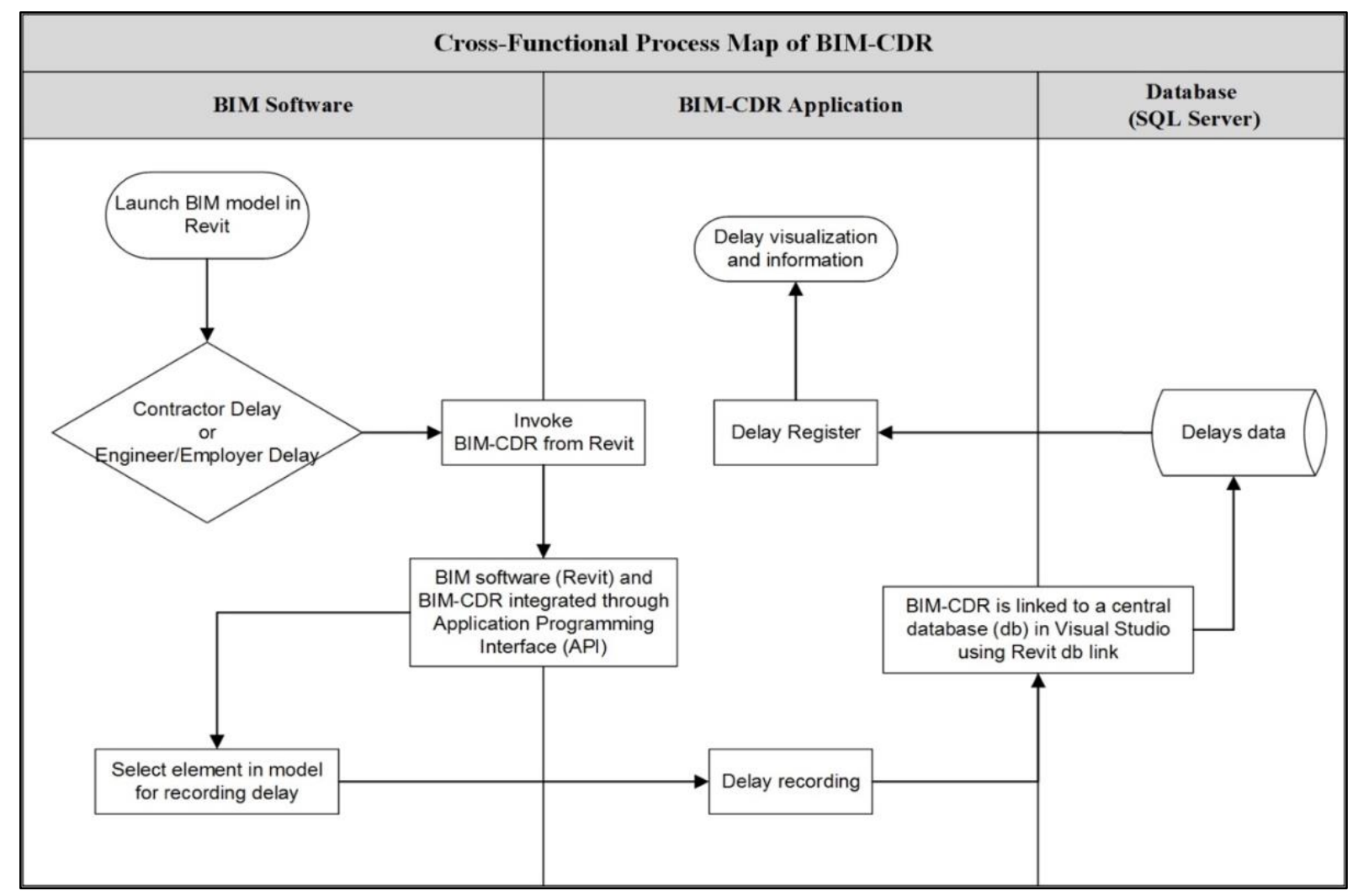

FIG. 2: BIM-CDR framework

\subsection{BIM-CDR prototype architecture}

The BIM-CDR prototype is developed in accordance with the Society of Construction Law Delay and Disruption Protocol recommendations (SCL 2017). BIM-CDR comprises of two modules: record module and delay register module. Outline of the developed plugin and its modules are displayed in Fig. 3. Each module and its functions are discussed in succeeding sub-sections.

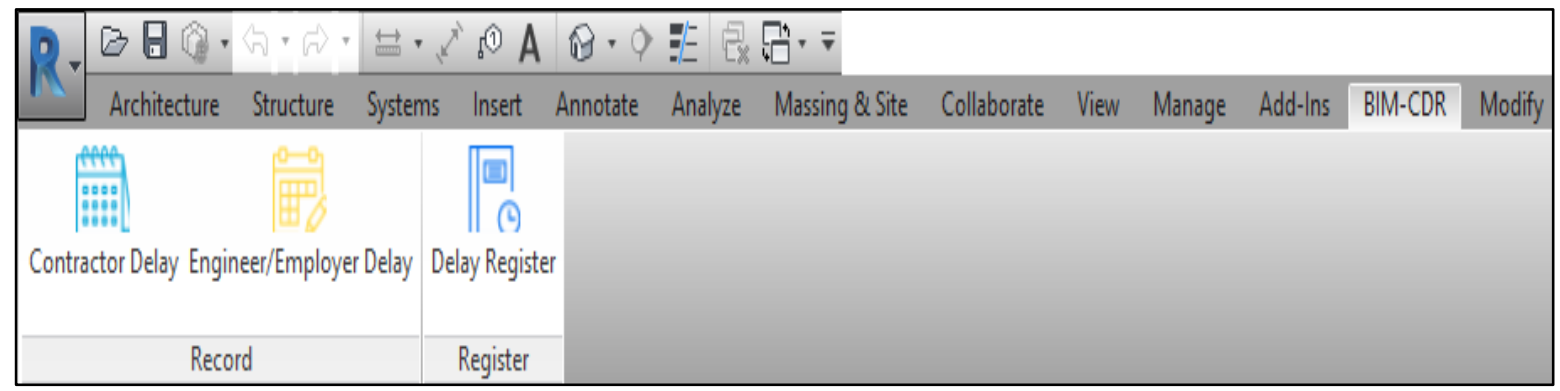

FIG. 3: User's interface screen for BIM-CDR plugin 


\subsubsection{Record module}

The record management of construction delay events has not been given due importance in the past. The absence of significant delay related information hinders in effective management of delay claims (Ho and Liu, 2004). In this research, importance of 'delays record management' is realized for effective management of construction delays. The record module of the developed BIM-CDR is provided with the option of 'Contractor's Delay' (that deals with delay event for which contractor is responsible) and 'Engineer/Employer's Delay' (which includes all other events, for which contractor is not responsible, as per contract agreement). It is also provided with the option of selecting the relevant type of delay.

Construction delays are commonly classified as excusable and non-excusable delays (Yogeswaran et al., 1998). Whether a delay is excusable or non-excusable, it is decided on the basis of provisions specified in the contract (Trauner, 2009). Excusable delay is an event characterized by the fact that the contractor was unable to foresee and control (Vasilyeva-Lyulina et al., 2015). Whereas, non-excusable delays are the ones for which contractor is either directly responsible or is assumed to have foreseen the delay-causing event (Mubarak, 2015). Excusable delays can be further categorized into excusable compensable and excusable non-compensable delays (Mubarak, 2015). The delays caused by the employer or his representative (The Engineer) are termed as compensable delays (Mubarak, 2015; Alaghbari et al., 2007). Delays in the issuance of drawings, different site conditions, variations in work and late site possession are some of the examples of compensable delays in many standard construction contracts (Shabbar et al., 2017; Alaghbari et al., 2007). Whereas, delays that are excusable in terms of time, but do not entitle the contractor to any monetary compensation, are called as non-compensable delays (Shabbar et al., 2017; Alaghbari et al., 2007). In the developed prototype, all possible types of delays are incorporated, including the contractor and employer caused delays.

For the template of Contractor's Delay, ten different categories are provided for data entry, as shown in Fig. 4 and Table 3. Whereas, for the template of Engineer/Employer's Delay, nine different categories are created for data entry, as shown in Fig. 5 and Table 4.

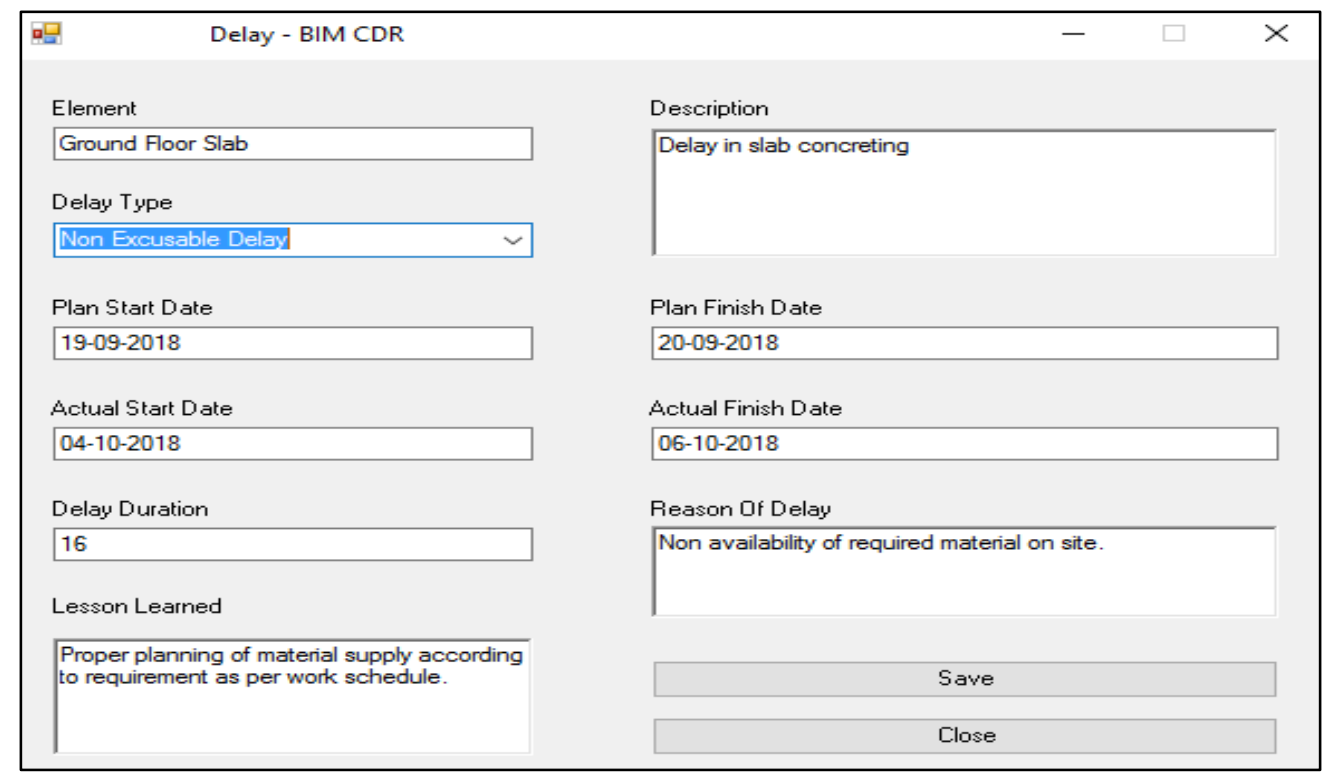

FIG.4: Information template for contractor's delay recording 
Table 3: Input categories for contractor's delay

\begin{tabular}{|c|c|c|}
\hline Category & \multicolumn{2}{|l|}{ Description } \\
\hline Element & \multicolumn{2}{|c|}{ Element name is automatically picked up for recording. } \\
\hline Description & \multicolumn{2}{|c|}{ Users enter brief about the delay event } \\
\hline Delay type & \multicolumn{2}{|c|}{$\begin{array}{l}\text { Users select suitable delay type (Non-Excusable Delay/ Excusable Non-Compensable } \\
\text { Delay) for the delay event }\end{array}$} \\
\hline Plan start date & \multicolumn{2}{|c|}{ Users enter plan start date of the delayed activity from the planned schedule } \\
\hline Plan finish date & \multicolumn{2}{|c|}{ Users enter plan finish date of the delayed activity from the planned schedule } \\
\hline Actual start date & \multicolumn{2}{|c|}{ Users enter actual date on which delayed activity is started } \\
\hline Actual finish date & \multicolumn{2}{|c|}{$\begin{array}{l}\text { Users at this stage or later during update stage, enter actual finish date on which activity } \\
\text { is finished }\end{array}$} \\
\hline Delay duration & \multicolumn{2}{|c|}{$\begin{array}{l}\text { Users enter the duration of the delay event or later update it when the delay period is } \\
\text { finished }\end{array}$} \\
\hline \multirow{2}{*}{$\begin{array}{l}\text { Reason of delay } \\
\text { Lesson learned }\end{array}$} & \multicolumn{2}{|c|}{ Users enter brief for the reasons due to which delay event has happened } \\
\hline & \multicolumn{2}{|c|}{$\begin{array}{l}\text { Users enter lesson learned from the delay, which should not be repeated in future for } \\
\text { better performance. This option is provided to enable the contractor for proactive } \\
\text { corrective actions against the occurrence of similar event in future }\end{array}$} \\
\hline Delay - & BIM CDR & $\square$ \\
\hline \multirow{2}{*}{\multicolumn{2}{|c|}{$\begin{array}{l}\text { Element } \\
18^{\prime \prime} \text { Foundation Raft }\end{array}$}} & Description \\
\hline & & Delay in Posession of Site \\
\hline \multicolumn{2}{|l|}{ Delay Type } & \\
\hline \multicolumn{2}{|l|}{ Excusable Compensable Delay } & \\
\hline \multicolumn{2}{|l|}{ Plan Start Date } & Plan Finish Date \\
\hline \multicolumn{2}{|l|}{ 15-06-2018 } & $30-06-2018$ \\
\hline \multicolumn{2}{|l|}{ Actual Start Date } & Actual Finish Date \\
\hline \multicolumn{2}{|l|}{$05-07-2018$} & \\
\hline \multicolumn{2}{|l|}{ Date Of Notification To Engineer } & Delay Duration \\
\hline \multicolumn{2}{|l|}{$05-07-2018$} & 20 \\
\hline & & Save \\
\hline & & Close \\
\hline
\end{tabular}

FIG. 5: Information template for Engineer/Employer's delay recording

Table 4: Input categories for Engineer/Employer's delay

\begin{tabular}{|c|c|}
\hline Category & Description \\
\hline Element & Element name is automatically picked up for recording. \\
\hline Description & Users enter brief about the delay event \\
\hline Delay type & $\begin{array}{l}\text { Users select suitable delay type (Excusable Compensable Delay/ Excusable Non-Compensable Delay) for } \\
\text { the delay event }\end{array}$ \\
\hline Plan start date & Users enter plan start date of the delayed activity from the planned schedule \\
\hline Plan finish date & Users enter plan finish date of the delayed activity from the planned schedule \\
\hline Actual start date & Users enter actual date on which delayed activity is started \\
\hline Actual finish date & $\begin{array}{l}\text { Users at this stage or later on, during the update stage, enter actual finish date on which delayed activity } \\
\text { is finished }\end{array}$ \\
\hline $\begin{array}{l}\text { Date of notification to the } \\
\text { Engineer }\end{array}$ & $\begin{array}{l}\text { Users enter the date on which contractor notifies the Engineer for the delay event as required by the } \\
\text { contract agreement }\end{array}$ \\
\hline Delay duration & Users enter the duration of the delay event or later update it when the delay period is finished \\
\hline
\end{tabular}




\subsubsection{Delay register module}

The interface of Delay Register is developed in accordance with the delay recording guidelines of Delay and Disruption Protocol of the Society of Construction Law (SCL 2017). It shows names of elements against which delay event data is entered, as shown in Fig. 6 and Fig. 7, separately for contractor's delays and Engineer/Employer's delays under different headings (tabs). It is also connected to a SQL database via Visual Studio to save the data entered in the record module. As a result, users can view that for which element in the model the data for the delay event is entered, and update the input values for the delay event, as shown in Fig. 8 and Fig. 9.

\begin{tabular}{|c|c|c|c|c|c|c|c|}
\hline \multicolumn{7}{|c|}{ Register - BIM CDR } & $-\quad \square$ \\
\hline \multicolumn{8}{|c|}{ Contractor Delay Engineer/Employer Delay } \\
\hline & $\mathrm{Sr} \mathrm{N}_{-} \mathrm{O}$ & Element & Delay_Duration & Plan_Start & Plan_finish & Actual_Start & Actual_Finish \\
\hline & 1 & GF Column 21"x21" & 4 & 10-08-2018 & 11.08-2018 & 14.08-2018 & 15-08-2018 \\
\hline & 2 & Ground Floor Slab & 16 & $19-09-2018$ & 20.09-2018 & $04 \cdot 10-2018$ & $06 \cdot 10-2018$ \\
\hline & 3 & 1st F Beam B-1 12" x 18" & 20 & $25-10-2018$ & 05-10-2018 & 25-10-2018 & $25 \cdot 11 \cdot 2018$ \\
\hline \multirow[t]{2}{*}{ - } & 4 & 2nd F Column C.1 21" $\times 21 "$ & 15 & 10-11-2018 & $20-11-2018$ & 10-11-2018 & 05-12:2018 \\
\hline & & & & & & & View And Update \\
\hline
\end{tabular}

FIG. 6. Template for recording contractor's delay

\begin{tabular}{|c|c|c|c|c|c|c|c|}
\hline 暍 & & gister - BIM CDR & & & & & - $\quad \square$ \\
\hline \multicolumn{2}{|c|}{ Contractor Delay } & Engineer/Employer Delay & & & & & \\
\hline & Sr_No & Element & Delay_Duration & Plan_Start & Plan_finish & Actual_Start & Actual_Finish \\
\hline & 1 & 18" Foundation Raft & 20 & 15-06-2018 & 30.06-2018 & 05.07.2018 & \\
\hline & 2 & Stair & 7 & 05-09-2018 & 07-09-2018 & 12.09-2018 & 14-09-2018 \\
\hline & 3 & 12" Floor & 10 & 10-10-2018 & 17-10-2018 & 10-10-2018 & $27 \cdot 10-2018$ \\
\hline & 4 & 2nd F Column C-121"x 21" & 5 & $07 \cdot 11 \cdot 2018$ & 15-11-2018 & 12.11.2018 & 20-11-2018 \\
\hline b & 5 & Beam $12^{\prime \prime} \times 18^{\prime \prime}$ & 20 & 10-11-2018 & 13-11-2018 & 30-11-2018 & 03-11-2018 \\
\hline & & & & & & & View And Update \\
\hline
\end{tabular}

FIG. 7: Template for recording Engineer/Employer's delay 


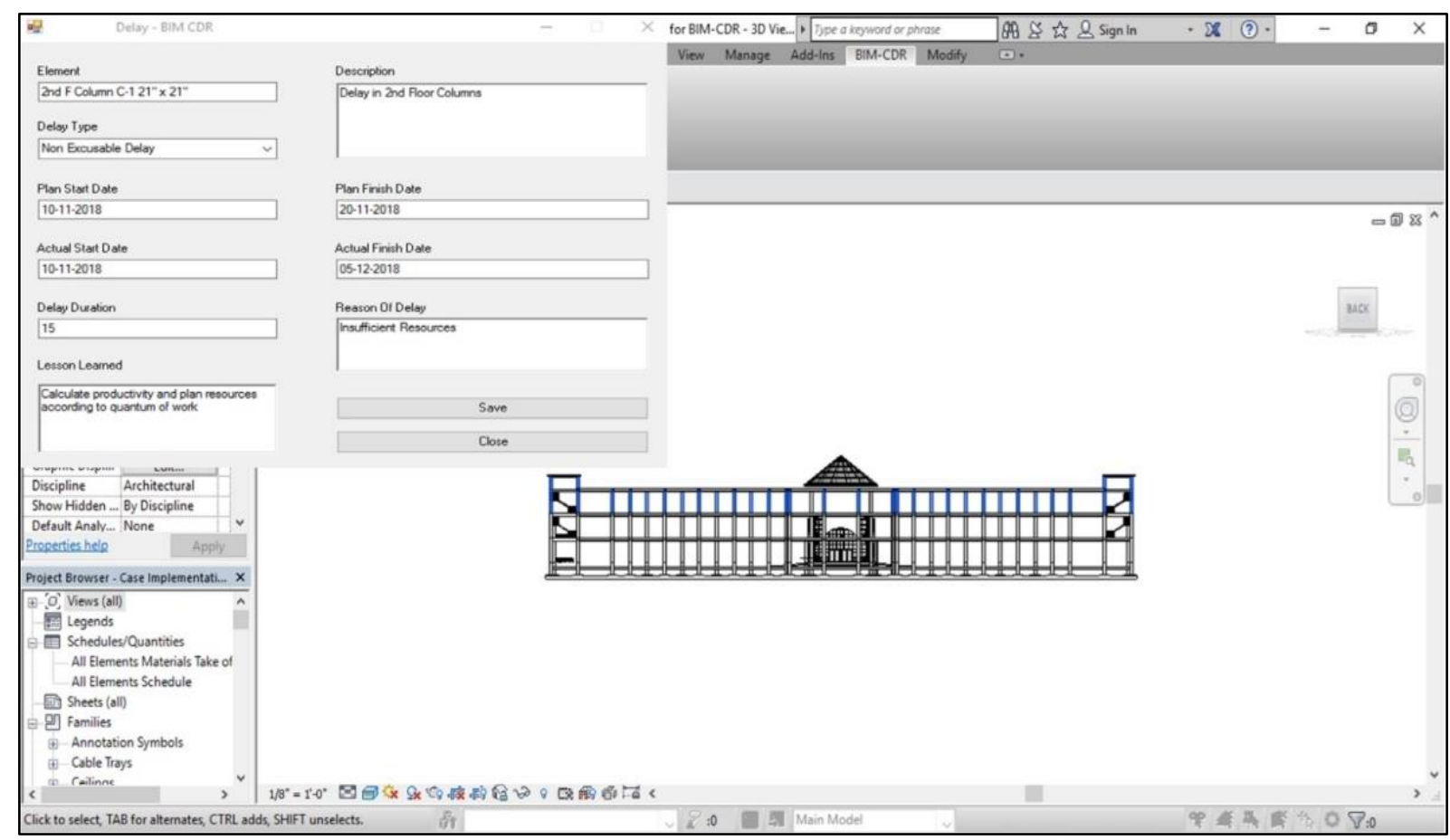

FIG. 8: Template showing information for contractor's delay

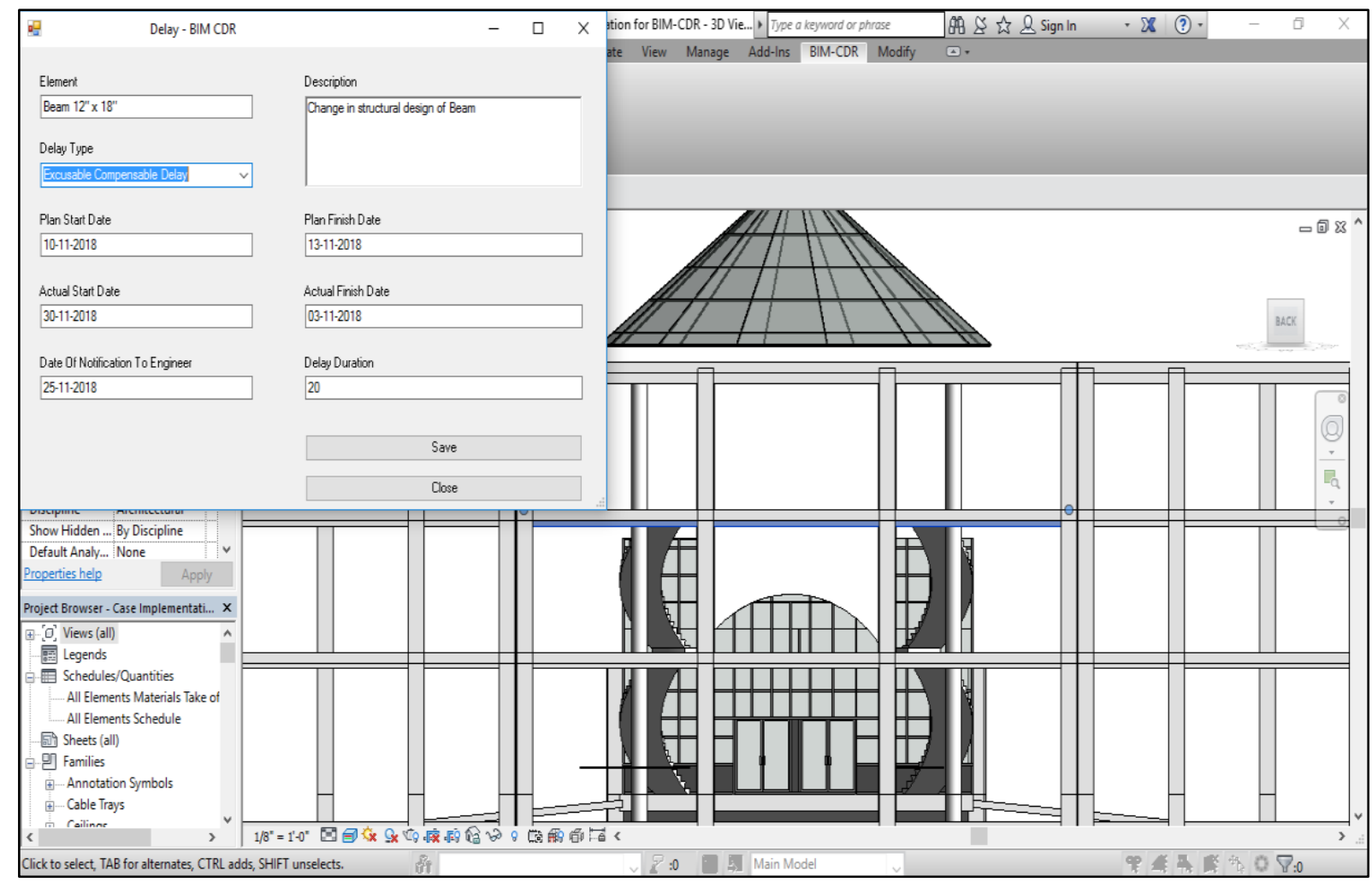

FIG. 9: Template showing information for Engineer/Employer's delay

\subsection{Evaluation of BIM-CDR: feasibility and discussion}

The developed prototype i.e. BIM-CDR was applied on a model project and demonstrated to industry experts, as shown in Fig. 2 to Fig. 8. Table 5 shows experts' responses based on the pre-defined evaluation criteria, which 
includes: need of BIM-CDR in construction industry, usability of BIM-CDR interface, possible implementation of BIM-CDR, and its overall effectiveness to improve the construction delays management. Similarly, Table 6 summarises the mean values, RII values, and ranking of the issues that can be effectively resolved using the developed BIM-CDR.

Table 5: Evaluation of the developed system i.e. BIM-CDR, by the industry's experts

\begin{tabular}{lccc}
\hline Evaluation criteria & Minimum score & Maximum score & Mean score \\
\hline Need & 4 & 5 & 4.3 \\
Usability & 3 & 5 & 3.8 \\
Implementation & 3 & 5 & 4.1 \\
Effectiveness & 4 & 5 & 4.5 \\
\hline
\end{tabular}

Table 6: Experts' opinion regarding the effectiveness of BIM-CDR in resolving delays management issues

\begin{tabular}{|c|c|c|c|c|c|}
\hline \multirow[t]{2}{*}{ No } & \multirow[t]{2}{*}{ Issues in delays management } & \multirow[t]{2}{*}{ Group } & \multicolumn{3}{|c|}{ BIM-CDR evaluation score } \\
\hline & & & Mean & RII & Rank \\
\hline 1 & $\begin{array}{l}\text { Inaccessibility of supporting documents needed for } \\
\text { notice }\end{array}$ & Documentation & 4 & 0.8 & 13 \\
\hline 2 & Unavailability of records for analysis & Documentation & 4.33 & 0.867 & 8 \\
\hline 3 & Inefficient record keeping system & Documentation & 4.73 & 0.9467 & 2 \\
\hline 4 & Overdue in retrieving the needed information & Time & 4.266 & 0.853 & 9 \\
\hline 5 & $\begin{array}{l}\text { Lack of timely decision by the Engineer regarding } \\
\text { delays }\end{array}$ & Time & 3.067 & 0.613 & 23 \\
\hline 6 & Lack of timely notifications by contractors & Time & 3.33 & 0.67 & 20 \\
\hline 7 & Engineer requests for excessive details & Time & 3.2 & 0.64 & 22 \\
\hline 8 & $\begin{array}{l}\text { Difficulty in categorization of different types of } \\
\text { delays }\end{array}$ & Contractual & 4.467 & 0.89 & 6 \\
\hline 9 & Lack of details submitted with notice & Contractual & 3.8 & 0.76 & 15 \\
\hline 10 & Poor paperwork by the contractor & Contractual & 4.4 & 0.88 & 7 \\
\hline 11 & Concurrent delays & Contractual & 3.866 & 0.773 & 14 \\
\hline 12 & Identification of responsibility of delay & Contractual & 4.53 & 0.9067 & 5 \\
\hline 13 & Noncompliance with contract requirements & Contractual & 3.267 & 0.653 & 21 \\
\hline 14 & Departure of related personnel from project & Resource & 4.067 & 0.813 & 12 \\
\hline 15 & Poor workmanship & Resource & 2.8 & 0.56 & 25 \\
\hline 16 & Lack of manpower and resources & Resource & 4.13 & 0.8267 & 11 \\
\hline 17 & No computerized documentation system & Resource & 4.867 & 0.973 & 1 \\
\hline 18 & Lack of communication & Procedure & 4.2 & 0.84 & 10 \\
\hline 19 & Complexity in determining cause and effect & Procedure & 4.67 & 0.933 & 3 \\
\hline 20 & Lack of updated program & Procedure & 3.4 & 0.68 & 19 \\
\hline 21 & Verbal Instructions & Procedure & 2.93 & 0.5867 & 24 \\
\hline 22 & Misleading information & Procedure & 3.467 & 0.693 & 18 \\
\hline 23 & Difficulty in visualization of delays impact & Presentation & 4.6 & 0.92 & 4 \\
\hline 24 & Presentation of delays & Presentation & 3.67 & 0.733 & 17 \\
\hline 25 & Exaggeration of delays impact by contractor & Cost & 3.73 & 0.7467 & 16 \\
\hline
\end{tabular}




\section{DISCUSSION}

Majority of the experts opined in favour of BIM-CDR, as the mean scores for its need, usability, implementation and effectiveness (as shown in Table 5) are ranging between agree to strongly agree. The experts agreed that the developed tool is surely required by the construction industry, and it will certainly be adopted by the construction stakeholders. It was graded as an effective tool to deal with construction delays. However, experts gave comparatively less scores to 'usability' of BIM-CDR. They were of the opinion that basic knowledge of BIM platform will be required to use this tool efficiently and for understanding the overall interface of BIM-CDR. It is justifiable as construction industry stakeholders are yet not well conversant with BIM technology (Ali et al., 2018).

\subsection{Effectiveness of BIM-CDR in resolving delays management issues}

The amicable effects of BIM-CDR in resolving the issues (Table 6), confronted during delays management, are discussed below:

- Documentation group: The results indicate that BIM-CDR is expected to address all documentationrelated problems in managing the construction delays, as most of the experts have scored in favour (agree to strongly agree). The second highest ranked problematic issue (i.e. inefficient record keeping system) is part of this group, which can be potentially eliminated by adopting BIM-CDR. The RII values indicate that over $80 \%$ issues belonging to documentation group would be resolved by adopting BIM-CDR.

- Time group: According to experts, BIM-CDR can reduce time in 'retrieving the documents' required for analyzing construction delays, therefore, it is ranked among the top ten problems that have been addressed using BIM-CDR. Other issues related to time group were relatively ranked lower by the experts, as indicated by RII scores. Experts believed that such issues occur due to personal indolence of the contractor as well as engineer, and bringing a new system may not change their behaviour and skills towards dealing with delays.

- Contractual group: The experts strongly believed that the issues pertaining to categorization and responsibility associated with the delays, and poor paperwork by contractor, can be greatly improved with the implementation of BIM-CDR. However, 'non-compliance with contract requirement' was ranked lower by the experts, as indicated by RII scores. Majority of the experts believed that this problem is related to individual's knowledge about contract and can be taken care of with a prerequisite knowledge of contractual obligations. According to the average scores of experts, the rest of the issues in this group can be resolved with BIM-CDR.

- Resource group: A mixed response was recorded for the issues related to the resource group. The issue of 'no computerized documentation system' is ranked much higher, while 'poor workmanship' was ranked the lowest among all the issues with an average score of less than 3 and a RII rating in the $50 \%$ range. Experts opined that the developed tool cannot be used as a substitute to poor work practices, being performed on project site. This problem will persist until related personnel are either trained or encouraged to deal with it in true spirit. Apart from the aforementioned issues, experts were convinced that BIM-CDR can be useful in disguising resource numbers limitations since it can be operated by one competent individual.

- $\quad$ Procedure group: The developed system is believed to provide an effective platform to minimize certain issues including: 'lack of communication' and 'complexity in determining cause and effect'. The issue of 'verbal instruction' screened out to be second last as per RII value. The experts opined that project stakeholders usually do not follow a documented channel so that they are not held responsible for causing delays. This issue can be resolved if the parties involved in a project follow a standard practice of providing documented instructions. The issues related to the availability of updated and accurate information are also considered to be problematic. The experts suggested that the engineer should play his part providing the most updated and accurate information throughout the duration of a project.

- Presentation group: Over $70 \%$ experts agreed that the issues pertaining to presentation group would no longer occur, especially the issue of "difficulty in visualisation of delays impact". It is considered to be among top five problems being resolved with the implementation of BIM-CDR.

- Cost group: The experts opined that contractor would not be able to overstate the losses due to delay, provided BIM-CDR is rightly implemented. 
Hence, except for the issues related to personal skills and nature of the contractor and engineer, BIM-CDR can be recognised as an efficient method to overcome the issues faced during the management of construction delays to a greater extent.

To improve the usability and implementation of BIM-CDR, experts suggested that an initial investment in terms of time and money for the initial training would be quite useful. They recommended an experimental exercise involving the employees in recording the delays information using BIM-CDR to make them realize about the benefits of developed system. It would also increase their motivation to learn this new technology. Some of the experts shared their experience of continuously endeavouring to implement the advance tools and techniques in their companies and providing training to educate their employees. The experts agreed that if implemented, the developed visualization tool would be a useful enhancement to existing delays management techniques. The inferences from the experts' opinion indicate a dire industry's need for the implementation of the created tool. It was quite encouraging that many experts requested to provide them with a version of the developed tool, after its demonstration; thus, signifying the necessity of the created tool for the construction industry.

\subsection{Benefits of BIM-CDR}

The benefits of BIM-CDR, agreed by majority of the experts after its demonstration, are summarized in Table 7 .

Table 7: Benefits of BIM-CDR

\begin{tabular}{|c|c|}
\hline Benefits & Description \\
\hline Delays management & $\begin{array}{l}\text { This development is beneficial for delays management and could greatly assist in delay analysis by } \\
\text { construction companies to support their claims for excusable delays. Likewise, engineering companies } \\
\text { can clearly decide the liabilities of contractor's delays. Also, concurrency of delays can easily be found. }\end{array}$ \\
\hline Easy to apprehend delays location & $\begin{array}{l}\text { The developed tool gives the contract experts a simple way to identify the locations where delays are } \\
\text { occurring and being reported }\end{array}$ \\
\hline Visualization of delays impact & $\begin{array}{l}\text { This technology improves the realization of impact of delays on the construction projects through } \\
\text { visualization, providing better presentation and understanding to authorities during decision making. }\end{array}$ \\
\hline Contract management & $\begin{array}{l}\text { This tool will provide potential enhancement in contract management when the contracting parties } \\
\text { would realize the capabilities and benefits of integrating BIM database with contracts. }\end{array}$ \\
\hline Dispute resolution & $\begin{array}{l}\text { If proper record keeping of delays is done through this tool, it can help during dispute resolution by } 3^{\text {rd }} \\
\text { parties i.e. Arbitrators, Mediators and later on in courts because of the transparency and understanding } \\
\text { of the delay events provided by this tool. }\end{array}$ \\
\hline Lesson learned & $\begin{array}{l}\text { Lesson learned feature equip the contractor with the ability to overview the contractor failures, not to } \\
\text { repeat them on other activities, and to complete the project within time. Moreover, record of the lessons, } \\
\text { learned from one project, can guide the contractor to efficiently plan another similar project. }\end{array}$ \\
\hline
\end{tabular}

\section{CONCLUSIONS AND RECOMMENDATIONS}

BIM implementation has improved the performance of various fields of construction management; however, it could not be explored to deal with construction delays due to non-availability of the associated features in BIM. An effort has been made, in this research, to equip BIM with the ability to record and manage construction delays. Accordingly, a prototype i.e. BIM-CDR is developed for recording and visualizing the construction delays information, using API of the most commonly used BIM software i.e. Autodesk Revit with C\# as a programming language. Contract personnel and key staff on construction projects can view and communicate accurate and timely information of the delays occurring at different stages of construction with the help of BIM-CDR. It also provides assistance in visualizing the location(s) of these delays, thus enabling the staff to analyse the impact of these delays on other components of a project. The feasibility of the developed prototype in dealing with construction delays is verified through industry's experts and practitioners. During the evaluation stage, BIM-CDR was implemented on a model project, and all the possible delays were recorded and presented to the experts. The opinion of experts was recorded during semi-structured interviews through a questionnaire survey. The experts highlighted the usefulness of BIM-CDR for construction industry and shared the ideas for enhancing its usability and implementation. 
The developed prototype will provide a centralized repository to construction stakeholders, which would: record the construction delay information and retrieve the related information for delay analysis in an existing scheduling tools; assist in visualizing the impact of delays; guide towards a transparent and quick settlement of delay claims; and help in nurturing exemplary relations between the contracting parties. It would also provide component-wise record of project delays and causes of these delays from contractor's point of view. Besides, it would enable the contractors to analyse the recorded information to avoid similar delays at later stages of an under-construction project, and during the execution of future projects.

Some of the possible barriers associated with the implementation of BIM-CDR that need to be overcome are: lack of BIM education of construction practitioners, cost and training involved in its implementation, reluctance of contracting parties for innovation in traditional construction practices, and limitation of contract clauses. In terms of usability, a substantial effort by project personnel is required to add all possible delay related information into BIM-CDR. These barriers can be greatly improved by calculating return on investment (ROI) for implementing BIM-CDR for managing delays in construction projects. This can be in the form of cost and time savings in avoiding disputes, and speedy settlement of delays' related compensation claims. Moreover, the recommendations given by the experts during the evaluation of BIM-CDR, as discussed in Section 4.1, will guide the stakeholders to transform the traditional delays management process into a digital, reliable, transparent and dispute-less environment. Likewise, future research should automate the data input process of BM-CDR.

Nevertheless, there are certain limitations to the scope of this study. Though, this study has adopted expert's evaluation method for evaluating BIM-CDR through its implementation on a model project of a medical complex, more practical testing of BIM-CDR on construction projects is recommended to analyze its outcomes in managing the delays. The future research may consider performing case studies for implementing BIM-CDR on construction projects.

\section{ACKNOWLEDGEMENTS}

The financial assistance from National University of Sciences and Technology (NUST), Pakistan, to undertake this research, is gratefully acknowledged. The authors also wish to thank the industry's experts who participated in the evaluation process of the developed tool. Lastly, reviewers' thoughtful suggestions and constructive comments to enhance the research quality are much appreciated.

\section{REFERENCES}

Abd El-Razek, M., Bassioni, H. \& Mobarak, A. (2008). Causes of delay in building construction projects in Egypt. Journal of construction engineering and management, 134, 831-841.

Akinade, O. O. (2017). BIM-based software for construction waste analytics using artificial intelligence hybrid models. Thesis, University of the West of England.

Akinade, O. O., Oyedele, L. O., Munir, K., Bilal, M., Ajayi, S. O., Owolabi, H. A., Alaka, H. A. \& Bello, S. A. (2016). Evaluation criteria for construction waste management tools: towards a holistic BIM framework. International Journal of Sustainable Building Technology and Urban Development, 7, 3-21.

Akintoye, A. \& Skitmore, M. (1991). Profitability of UK construction contractors. Construction Management and Economics, 9, 311-325.

Alaghbari, W. e., Razali A. Kadir, M., Salim, A. \& Ernawati (2007). The significant factors causing delay of building construction projects in Malaysia. Engineering, Construction and Architectural Management, 14, 192-206.

Ali, B., Zahoor, H., Mazher, K. M. \& Maqsoom, A. (2018). BIM Implementation in Public Sector of Pakistan Construction Industry. In ASCE's Conference (ICCREM 2018 - Innovative Technology and Intelligent Construction), December 9-10, (pp. 42-51), South Carolina, USA. https://goo.g1/M7tTfS

Ali, B., Zahoor, H., Nasir, A. R., Maqsoom, A., Khan, R. W. A. \& Mazher, K. M. (2020). BIM-based claims management system: A centralized information repository for extension of time claims. Automation in Construction, 110 (2), 1-16, 102937.

Alkass, S., Mazerolle, M., Tribaldos, E. \& Harris, F. (1995). Computer aided construction delay analysis and claims preparation. Construction Management and Economics, 13, 335-352. 
Alnaas, K. A. A., Khalil, A. H. H. \& Nassar, G. E. (2014). "Guideline for preparing comprehensive extension of time (EoT) claim". HBRC Journal, 10, 308-316.

Arif, F. \& Morad, A. A. (2013). Concurrent delays in construction: International legal perspective. Journal of Legal Affairs and Dispute Resolution in Engineering and Construction, 6, 04513001.

Arcadis. (2020). Global Construction Dispute Report. Available at https://www.arcadis.com/en/knowledgehub/perspectives/middle-east/2020/global-construction-disputes-report-2020 (Accessed 15 May 2021).

Arslan, M., Riaz, Z., Kiani, A. K. \& Azhar, S. (2014). Real-time environmental monitoring, visualization and notification system for construction H\&S management". Journal of Information Technology in Construction (ITcon), 19, 72-91.

Azhar, S., Ahmad, I. \& Sein, M. K. (2009). Action research as a proactive research method for construction engineering and management. Journal of Construction Engineering and Management, 136, 87-98.

Bakhary, N. A., Adnan, H. \& Ibrahim, A. (2015). A study of construction claim management problems in Malaysia. Procedia economics and finance, 23, 63-70.

Bakhary, N. A., Adnan, H. \& Ibrahim, A. (2017). Improving construction claim management in Malaysian construction industry. MATEC Web of Conferences, 2017. EDP Sciences, 05003.

Bouchlaghem, D., Shang, H., Whyte, J. \& Ganah, A. (2005). Visualisation in architecture, engineering and construction (AEC). Automation in construction, 14, 287-295.

Braimah, N. (2013). Understanding construction delay analysis and the role of preconstruction programming. Journal of Management in Engineering, 30, 04014023.

Burr, A. \& Pickavance, K. (2010). The use of visualisations in case presentation and evidence. Construction Law Journal, 26, 3-1.

Carmichael, S. \& Murray, M. (2006). Record keeping for contemporaneous delay analysis: A model for effective event management. Construction Management and Economics, 24, 1007-1018.

Creswell, J. W. (1998). Qualitative inquiry and research design: Choosing among five traditions: Thousand Oaks, CA: Sage Publications. 0761901434.

Enshassi, A., Mohamed, S. \& El-Ghandour, S. (2009). Problems associated with the process of claim management in Palestine: Contractors' perspective. Engineering, construction and architectural management, 16, 6172.

Farrow, T. (2007). Developments in the analysis of extensions of time. Journal of Professional Issues in Engineering Education and Practice, 133, 218-228.

Gibbs, D.-J., Emmitt, S., Ruikar, K. \& Lord, W. (2014). Recommendations on the creation of computer generated exhibits for construction delay claims. Construction Law Journal, 30, 236-248.

Guest, G., Bunce, A. \& Johnson, L. (2006). How many interviews are enough? An experiment with data saturation and variability". Field methods, 18, 59-82.

Hanna, A. S., Nassereddine, H. \& Swanson, J. R. (2017). Proper risk allocation: NDFD clause. Journal of Legal Affairs and Dispute Resolution in Engineering and Construction, 9, 04516014.

Hassanein, A. A. \& El Nemr, W. (2008). Claims management in the Egyptian industrial construction sector: a contractor's perspective. Engineering, Construction and Architectural Management, 15, 246-259.

Ho, S.-P., Tserng, H.-P. \& Jan, S.-H. (2013). Enhancing knowledge sharing management using BIM technology in construction. The Scientific World Journal, 2013.

Ho, S. P. \& Liu, L. Y. (2004). Analytical model for analyzing construction claims and opportunistic bidding. Journal of construction engineering and management, 130, 94-104.

Hsieh, H.-F. \& Shannon, S. E. (2005). Three approaches to qualitative content analysis. Qualitative health research, $15,1277-1288$. 
Kumaraswamy, M. M. (1997). Conflicts, claims and disputes in construction. Engineering, construction and architectural management, 4, 95-111.

Larsen, J. K., Shen, G. Q., Lindhard, S. M. \& Brunoe, T. D. (2015). Factors affecting schedule delay, cost overrun, and quality level in public construction projects. Journal of Management in Engineering, 32, 04015032.

Lee, D.-G., Park, J.-Y. \& Song, S.-H. (2018). BIM-Based Construction Information Management Framework for Site Information Management. Advances in Civil Engineering, 2018.

Maduranga, J., Palamakumbura, A. \& Dissanayake, P. (2017). Preparation of extension of time (EOT) claims and delay analysis techniques used in the construction industry.

Mahamid, I., Bruland, A. \& Dmaidi, N. (2011). Causes of delay in road construction projects. Journal of Management in Engineering, 28, 300-310.

Marzouk, M., Othman, A., Enaba, M. \& Zaher, M. (2018). Using BIM to Identify Claims Early in the Construction Industry: Case Study. Journal of Legal Affairs and Dispute Resolution in Engineering and Construction, 10,05018001 .

Moayeri, V., Moselhi, O. \& Zhu, Z. (2017). BIM-based model for quantifying the design change time ripple effect. Canadian Journal of Civil Engineering, 44, 626-642.

Mubarak, S. A. (2015). Construction project scheduling and control, Published, John Wiley \& Sons,Place.

Muhamad, N. H., Mohammad, M. F., Ahmad, A. C. \& Ibrahim, I. H. (2016). Delay analysis methodologies (DAMs) in delivering quality projects: Contractors and consultants' perceptions. Procedia-Social and Behavioral Sciences, 222, 121-131.

NBS (2017). What is BIM?, Available at: https://www.thenbs.com/knowledge/what-is-building-informationmodelling-bim (Accessed 30 May 2018).

Paek, T. (2001). "Empirical methods for evaluating dialog systems. Proceedings of the workshop on Evaluation for Language and Dialogue Systems-Volume 9, 2001. Association for Computational Linguistics, 2.

Palaneeswaran, E. \& Kumaraswamy, M. M. (2008). An integrated decision support system for dealing with time extension entitlements. Automation in Construction, 17, 425-438.

Pickavance, K. (2010). Delay and disruption in construction contracts, Published, Sweet \& Maxwell,Place.

Riaz, Z., Arslan, M., Kiani, A. K. \& Azhar, S. (2014). CoSMoS: A BIM and wireless sensor based integrated solution for worker safety in confined spaces. Automation in construction, 45, 96-106.

Schumacher, L. (1995). Quantifying and apportioning delay on construction projects. Cost engineering, 37, 11.

Scott, S. (1997). Delay claims in UK contracts. Journal of construction engineering and management, 123, 238244.

Scott, S., Harris, R. A. \& Greenwood, D. (2004). Assessing the new United Kingdom protocol for dealing with delay and disruption. Journal of Professional Issues in Engineering Education and Practice, 130, 50-59.

Shabbar, H., Ullah, F., Ayub, B., Thaheem, M. J. \& Gabriel, H. F. (2017). Empirical Evidence of Extension of Time in Construction Projects. Journal of Legal Affairs and Dispute Resolution in Engineering and Construction, 9, 04517008.

Shahhosseini, V. \& Hajarolasvadi, H. (2018). A conceptual framework for developing a BIM-enabled claim management system. International Journal of Construction Management, 1-15.

Shen, X. a. M., E. (2015). Near-Miss Information Visualization Tool in BIM. Journal of Construction Engineering and Management, ASCE, 04015100-1-04015100- 10.

Tan, H. C. \& Anumba, C. (2010). Web-based Construction Claims Management System: A Conceptual Framework. Proceedings of the 8th International Conference on Construction and Real Estate Management (ICCREM 2010). 1-3. 
Trauner, T. J. (2009). Construction delays: Understanding them clearly, analyzing them correctly, Published, Butterworth-Heinemann,Place.

Vasilyeva-Lyulina, A., Onishi, M. \& Kobayashi, K. (2015). Delay analysis methods for construction projects: Mathematical modelling. Int. J. Transp, 3, 27-36.

Vidogah, W. \& Ndekugri, I. (1997). Improving management of claims: contractors' perspective. Journal of Management in Engineering, 13, 37-44.

Yates, J. \& Epstein, A. (2006). Avoiding and minimizing construction delay claim disputes in relational contracting. Journal of Professional Issues in Engineering Education and Practice, 132, 168-179.

Ying-Mei, C. (2017). Application of BIM on Documenting Construction Defects. International Journal of Engineering and Technology, 9, 392.

Yogeswaran, K., Kumaraswamy, M. M. \& Miller, D. R. (1998). Claims for extensions of time in civil engineering projects. Construction Management \& Economics, 16, 283-293.

Yoke-Lian, L., Hassim, S., Muniandy, R. \& Mee-Ling, T. (2012). The assessment of applications for extension of time claims in Malaysian construction industry. International Journal of Engineering and Technology, 4, 446.

Yusuwan, N. M. \& Adnan, H. (2013). Issues associated with extension of time (EoT) claim in Malaysian construction industry. Procedia Technology, 9, 740-749.

Zahoor, H., Chan, A. P., Utama, W. P., Gao, R. \& Memon, S. A. (2017). Determinants of safety climate for building projects: SEM-based cross-validation study. ASCE's Journal of Construction Engineering and Management, 143(6), 05017005. 